наполненность религиозно-нравственных поисков киевских академистов заключалась в своеобразном видении и толковании проблем добродетелей, обязанности и идеи блага. Идейными истоками этических идей мыслителей Киевской духовной академии являются произведения отиов иеркви в византийской интерпретации, с одной стороны, а с другой - моральная философия Канта, Фихте и других немецких философов этического толка.

Ключевые слова: теистическая этика, моральная философия, нравственность, богословские добродетели, нравственный идеал, благо.

I. V. Kondratyeva, Doctor of Philosophical Science, Assosiate Professor

Taras Shevchenko National University of Kyiv

60, Volodymyrska Street, Kyiv, 01033, Ukraine

\title{
THE CONCEPT GENESIS OF THE ETHICAL DOCTRINES OF KIEV ACADEMISTS
}

The article reveals the reasons for the Kyiv thinkers to emphasize their ethical issues in their creative intelligence. Most of all there was need for justification in the light of the moral postulates of metaphysical epistemological and eschatological developments, an updated tendency towards the injection of ethics in philosophical concepts which is characteristic to the development of European thought of the second half of the nineteenth century, needs of social practice, distribution of nihilistic ideas in society.

The process of forming the ethical academic doctrine cannot be conceived without solving the problem of ideological influences. The following processes are recognized by: a) Mainly but not exclusively the Eastern-Byzantine tradition which was a logical extension of holy teachings; b) Influence of Kant's moral philosophy and in part Fichte's and theist-oriented theories of German thinkers of the nineteenth century.

The ideas of the moral-educational character contained in the works of the holy fathers and teachers of the church, in particular Athanasius the Great, John Chrysostom, John Climacus, Ambrose of Mediolans, who are subsequently influenced the formation of the ethical doctrine of the Kyiv thinkers. The ideological discrepancy between spiritual philosophers and their predecessors - professors of the Kyiv-Mohyla Academy, who came out in their intelligence from the provisions of Aristotelian ethics, is emphasized. Reasons of the influence of German idealism were found in particular practical philosophy on the process of formation of ethical attitudes of Kyiv academicians. Separately the most influential researchers of the idea of the moral philosophy of Kant and the principle of morality a priori are considered. In order to identify possible recipes of theistic concepts of German thinkers the main propositions of the theologies of morality explained by A. Richel, F. Schleiermacher, H. Martensen, A. Wutke, R. Root, A. Ettingen, K. Palmer. Actually the ethical doctrine of the thinkers of the Kiev Theological Academy is actualized on the one hand through the creative processing of the ideological achievements of patristics, on the other hand the concepts of the practical philosophy of German idealism.

Key words: theistic ethics, moral philosophy, morality, theological virtues, moral ideal, good.

УдК 130.2:[7.035.7:7.045](4)

Н. Ю. Кривда, д-р філос. наук, проф. Київський національний університет імені Тараса Шевченка вул. Володимирська, 60, м. Київ, 01033, Україна n.kryvda@britishmba.in.ua

\section{КОНСТРУЮВАННЯ УКРАÏНСЬКОЇ ІДЕНТИЧНОСТІ: ВИКЛИКИ КОМЕМОРАЦІї}

У статmі здіснюється культурософський аналіз концепції національної ідентичності у контексті "винайдення традиції". Під час формування колективної ідентичності маємо підстави вважати, що "винайдення" відповідної часу традиції є одним із головних засобів подолання стереотипів і практик, які вважаються застарілими і не відповідають покладеній на них фуункції - консолідації суспільства. Ідеї, символи та "місця пам'яті", які отримують нове змістовне наповнення, сприяють руйнуванню тих соціальних моделей, які підтримувались старою традицією, руйнуючи її саму. Саме тому у процесі конструювання традиції пери за все береться до уваги те, що суголосне сучасності, актуалізується нею і відповідає поставленим політичним цілям, натомість "забувається" те, що перешкоджає їх досягненню. У даному контексті важливого значення набуває поняття комеморації, що виступає як дієвий інструмент формування колективної ідентичності та засіб консервації історічної пам'яті.

Ключові слова: ідентичність, колективна пам'ять, історична пам'ять, комеморація, консолідація, традиція, культура.

Постановка проблеми. Після здобуття Україною незалежності актуалізується питання створення цілеспрямованої символічної політики, яка б змогла знівелювати різновекторні геополітичні та цивілізаційні орієнтації українського суспільства, забезпечивши тим самим територіальну цілісність України, шляхом свідомого конструювання новітньої української ідентичності. Попри це українська політична еліта продовжує впроваджувати сформовані в радянський період практики, спрямовані на пошук та захист від "Чужого", яким у сучасному українському соціумі став не тільки зовнішній, а й внутрішній "Інший", що призвело як до "цивілізаційного розколу" (С. Хантінгтон) українського суспільства, так і мілітарної кризи. Тому надзвичайно важливим постає той фракт, що національна ідентичність мала б вибудовуватися на принципах громадянства, пом'якшуючи етнічні, расові, мовні, культурні, релігійні та інші відмінності, шляхом впровадження аксіологічної та символічної сіток, які б змогли отримати резонанс у поліетнічному українському соціумі. Аналіз загальнонаціональної ідентичності дає змогу з'ясувати сутність сконструйованого характеру, у процесі фрормування якої ключову роль відіграють "місця пам'яті" та стратегії комеморації.

Аналіз досліджень і публікацій. До аналізу проблематики національної ідентичності та комеморації звертались наступні науковці: 3. Бауман, Е. Гобсбаум, Дж. Елів, Д. Лангевіше, М. Маколі, А. Мегілл, П. Нора, Дж. Пламенац, Т. Ренджер, Є. Романовська, Е. Сміт, Р. Суді, М. Фуше, С. Хантінгтон, П. Штомпка.
Серед українських дослідників проблематику національної ідентичності та комеморації розглядали О.Гнатюк, О. Гринів, В. Грицай, М. Жулинський, Г. Корж, В. Кравченко, В. Кремень, Л. Лазурко, Ф. Медвідь, М. Ніколко, О. Охрімчук, В. Піскун, Т. Потапчук, Ю. Рубан, В. Сергійчук, Є. Сверстюк, І. Юхновський, В. Яворівський.

Мета статті. Визначити основоположні засади національної ідентичності у її тісному взаємозв'язку 3 традицією та історичною пам'яттю, а також сфрормувати уявлення про комеморацію як дієвий інструмент для формування колективної ідентичності.

Виклад основного матеріалу дослідження. Складність історичних викликів, що постали перед Україною "тепер і зараз", змушують з напруженим інтересом придивлятися до змісту, функцій, а головне - трансформацій колективної пам'яті українців. Можна констатувати тенденцію до вихолощення радянського історичного/культурного наративу, з іншого боку, помітна інтенсифікація альтернативних пошуків, що характеризуються творенням "коротких" наративів, увічненням недавніх подій.

Декомунізація соціокультурного буття супроводжується пожвавленням інтересу до культурної спадщини та історичного минулого спільноти як засобів консолідації суспільства. Тлом консолідації певний час була ідея "національного відродження" спільноти, яка сформувалася на початку XX ст. і, власне, не утрималась на політичній арені не стільки через політичне безсилля, скільки через руйнівний вплив тоталітарної радянської 
системи. В Україні наразі не відбулося "винайдення традиції" (Е. Гобсбаум), процес декомунізації співіснує із трансляцією в суспільну свідомість дорадянської історичної/інтелектуальної спадщини, що актуалізує інтелектуальну спадщину М. Грушевського з акцентом на понятті "народ", який розглядався як споконвічна несвідома даність, яка під впливом історичних колізій втратила власний політичний вектор. Вважалось, що щойно світло просвіти пробудить свідомість народу, він одразу ж вийде із політичного небуття і швидкими темпами рухатиметься до "світлого майбутнього".

В дійсності повернення до інтелектуальної спадщини XIX ст. може мати певні згубні наслідки для українського соціуму. По-перше, інтелектуальна думка цього періоду оберталася навколо концепту єдності православних слов'яно-руських народностей, а відтак, була позначена високим рівнем ворожості до католицького Заходу, який сьогодні $є$ цивілізаційним орієнтиром України. По-друге, й інтелектуальний дискурс XIX ст., і національний рух початку XX ст. були зосереджені на конструюванні етнічної нації, що є закономірним з огляду на дієвий спосіб формування територіальної ідентичності.

Важливо розглянути традицію як продукт певної соціальної інженерії. Два різновекторні символічні капітали є виразним свідченням кризи української ідентичнос$\mathrm{Ti}$, подолати яку, за твердженням Е. Гобсбаума, можна через конструювання деякої сукупності "суспільних практик, як правило, обмежених відкрито або мовчазно визнаними правилами ритуального або символічного характеру, спрямованих на прищеплення певних цінностей і норм поведінки шляхом повторення, яке автоматично має на увазі спадкоємність 3 минулим" [25, с. 12]. Наразі в Україні назріла гостра потреба у "винайденні традиції", що не буде зведена до усього історичного досвіду спільноти, оскільки, за слушним зауваженням П. Штомпки, "сума подій за час існування людства, - не традиція, а скоріше генеалогія суспільства..." [20, с. 90-91]. Традиція, продовжує дослідник, - це не щось стихійне або органічно сформоване в ході історичного розвитку спільноти, навпаки, традиція - це завжди результат свідомого вибору, бо вона свідомо обирається і твориться відповідно до нинішніх потреб і прагнень певної історичної ситуації [19, с. 350]. Традиція виникає в результаті свідомого і цілеспрямованого осмислення та переосмислення подій минулого, у підсумку чого виникає образ "уявного", а часто навіть "ідеального минулого". Вона формує і закріплює в суспільній свідомості деякий образ "Ми", який відрізняється від "Вони".

Символічний образ "Ми" завжди передбачає протиставлення "Вони", зберігаючи міфологічну біполярну модель світу, хоча таке протиставлення у сучасному світі має не такий антагоністичний сенс, як у премодерних суспільствах. Модерне конструювання традицій відбувається під впливом таких цивілізаційних змін, які спільнота вважає своїми. В даному контексті важливо почути С. Гантінгтона щодо непересічної ролі релігійних цінностей у формуванні великих цивілізаційних просторів і водночас його засторогу: спроби цивілізаційного "перевизначення" наразі ніде не увінчалися успіхом [18]. Відзначимо в цьому контексті контраверсійність українського досвіду: з одного боку, визначеність українського соціуму православ'ям, яке "підштовхує" українців у полон "руського миру", з іншого боку, зародження української ідентичності, як зауважував Дж. Пламенац, відбувалося під впливом західних ідей і практик $[11$, с. 488], які набували неабиякого поширення серед найбільш свідомих представників тогочасного українства (М. Драгоманов, І. Франко, Б. Кістяківський та ін.), що прагнули сформувати символічний капітал, орієнтуючись на базові європейські цінності та ідеї.
Маємо підстави вважати, що "винайдення" відповідної часу традиції $€$ одним із головних засобів подолання стереотипів і практик, які вважаються застарілими і не відповідають покладеній на них функції - консолідації суспільства, яка відбувається у підсумку формування колективної ідентичності. Ідеї, символи та "місця пам'яті", які отримують нове змістовне наповнення, сприяють руйнуванню тих соціальних моделей, які підтримувалися старою традицією, руйнуючи її саму. Зауважимо, що "винайдення традиції" зазвичай відбувається через звернення до історичного минулого, яке в нових умовах отримує нове змістове наповнення. Зважаючи на сказане, маємо всі підстави погодитися 3 П. Нора в тому, що "історична пам'ять завжди сьогодення" [23, с. 289]. Адже, здійснюючи вибір подій і способів увічнення минулого, національні еліти одночасно обирають майбутне спільноти. "Нація, - зауважують Р. Суні і Дж. Елів, - артикулюється за допомогою складного процесу культурної інновації, який пов'язаний 3 серйозною ідеологічною роботою, інтенсивною пропагандою і вимагає творчого підходу. Важливу роль в цьому процесі відіграють формування та подальше використання особливих уявлень про минуле, які повинні служити підставою для вимог культурної автономії і, в кінцевому рахунку, - політичної незалежності" [21, с. 7-8]. Саме тому в процесі конструювання традиції перш за все береться до уваги те, що суголосне сучасності, актуалізується нею і відповідає поставленим політичним цілям, натомість "забувається" те, що перешкоджає їх досягненню. Інакше кажучи, політика пам'яті, яка виявляється у "винайденні традиції", відіграє амбівалентну роль: з одного боку, вона конструює такі проекти минулого, які забезпечать консолідацію суспільства та визначать вектор соціокультурного та політичного розвитку спільноти, а з іншого - актуалізується як практика вибіркового забуття.

Відзначимо, що саме комеморація є одним із дієвих інструментів "винайдення традиції". Конструювання традиції, яка виявляється у вигляді своєрідного символічного універсуму спільноти та відповідної йому ритуально-обрядової (в тому числі політичної) практики, часто супроводжується ідеалізацією та/або фальсифікацією минулого. Для опису тих численних способів "виробництва пам'яті", за допомогою яких у суспільстві закріплюється, зберігається і передається пам'ять про минуле, П. Нора вводить поняття "комеморація" [23, с. 19]. У вузькому значенні цей термін позначає увічнення пам'яті про події: спорудження пам'ятників та музеїв, визначення важливих дат, свят, проведення масових заходів, а також різного роду артефакти, ідеї та тексти, які визначають меморіальну діяльність. У більш широкому значенні термін комеморація позначає все те, що єднає людину або спільноту з минулим. Комеморація як інструмент формування колективної ідентичності широко використовувалася протягом усієї історії людства. В архаїчному суспільстві спільні спогади підкріплювалися регулярними ритуалами, які символізували відтворення встановленого "од віку" світопорядку. Своєрідність ритуалів, культурних/релігійних практик, разом з мовою, була головним маркером розрізнення спільнот, водночас підтримуючи їх внутрішню єдність [11, с. 83].

Не менш показовим прикладом впливу комеморації на формування світобачення, а з ним і колективної ідентичності виступає середньовічна пам'ять. Ї̈̈ осердям, доводить Ю.Арнаутова, спираючись на зауваги О. Ексле, була поминальна практика, в основі якої лежали два уявлення: абсолютна віра у те, що смерть не припиняе людського існування, і в те, що називання імені рівнозначне присутності померлого чи відсутньо- 
го. В премодерному світогляді, в усних культурах, "ім'я" та "буття" розглядалися як тотожні [1]. В середньовічній українській культурі на цьому ж світоглядному тлі, в тому числі, сорормувалася практика глибокого шанування ікон та святих. Вшанування місцевих святих було одним із чинників формування групової єдності [1]. Правомірність зроблених дослідницею висновків підтверджується і своєрідністю формування колективної ідентичності українців, яке відбувалося на тлі спільної обрядової практики та навколо шанованих у певному соціокультурному середовищі ікон, які слугували візуальним маркером структурування соціального простору, ритуально розмежовуючи своїх/чужих.

Десакралізація світу, яка розпочалася в модерний період, та вихід на авансцену історії національних держав виявили неспроможність старих фрорм комеморації забезпечити колективну єдність та суспільну ідентичність всередині країни. Це породило потребу у створенні нової традиції та введенні символів, які б забезпечували почуття колективної ідентичності. Звичайно, поряд із такими новоствореними символами, як державний герб, прапор, гімн тощо, важливе місце у цьому процесі займало збереження у представників нової спільноти відчуття інтуїтивної єдності із минулим, яке забезпечувалося встановленням пам'ятників, монументів, спорудженням адміністративних будівель тощо. Особливу ж роль у цьому процесі відгравали національні свята, які розглядалися як один із найголовніших засобів досягнення єдності і водночас у символічних картинах і образах спроектувати майбутнє [8, с. 91].

Д. Лангевіше розглядав національні свята як один із найважливіших інструментів символічної політики, спрямованої на формування національної ідентичності. "“Народ", що приходив на свято, мав лишити вдома свої "давні, огидні, позбавлені смаку і простацькі пісеньки" і призвичаюватися до громадянських норм поведінки" [8, с. 91]. Отже, завдання національного (як і державного) свята як одного із елементів "винайденої традиції" полягало [і полягає - уточ. наше] у "соціалізації закарбуванні у свідомості вірувань, систем цінності та правил поведінки" [25, с. 56]. Маємо всі підстави погодитися з висновком про те, що виникнення національних свят стало закономірним результатом "кардинальних трансформацій соціальних груп, навколишнього середовища та соціального контексту, який потребував нових механізмів забезпечення і вираження соціальної згуртованості та ідентичності, а також структурування суспільних відносин" [25, с. 263].

Утвердження національних свят відбувалося під впливом комеморації, засвідчує проаналізований Е. Гобсбаумом зміст національних свят Франції, про те саме свідчить і сучасна українська символічна політика - при всіх наших претензіях до їі формування. Показовим прикладом може слугувати православне свято Покрови Богородиці 14 жовтня, у святкуванні та ритуалах якого перехрещуються кілька символічних рядів. Поряд із вірою у святе заступництво Богородиці з омофором в руках Покрова символізувала також кінець землеробських робіт. Від Покрови селяни очікували перших заморозків та першого снігу, від кількості якого залежали врожаї озимини, добробут населення. Після Покрови святкували весілля. "Покрова накриває траву листям, землю снігом, воду - льодом, а дівчат шлюбним вінцем". Плат-покров на голові з'являвся після заміжжя, заступництво над яким було надано Богородиці Покрові. Ще один символічний шар - козацький. В цей день обирали нового отамана. Свята Покрова охороняє, Пресвята Богородиця - заступниця та покровителька козацької спільноти. Найдавнішою Покровською церквою вважається споруда 1467 року у Сутківцях Хмельницької області. В роки Другої світової Українська повстанська армія (УПА) обрала свято Покрови як День зброї, віддавшись під опіку Святої Покрови. В часи незалежності з 1999-го свято Покрови святкувалося як День українського козацтва.

Від 2014-го це свято набуло статусу загальнонаціонального - 14 жовтня українці відзначають не тільки як православне чи козацьке свято, а й як День захисника Вітчизни (День захисника України). При цьому його первинне десакралізоване символічне навантаження, зокрема зв'язок із УПА, підтримується у західних регіонах країни, де поки що зберігається живий зв'язок із представниками українського національного руху. Натомість у свідомості більшості населення слово "захисник" не зводиться до жодної політичної чи ідеологічної парадигми, а має широкий світоглядний контекст.

Більш проблематичним, на наш погляд, є законодавче закріплення статусу національних за великими православними святами (Різдво, Великдень, Трійця) та започаткованими у радянський період (1-2 травня - День солідарності трудящих - День міжнародної солідарності трудящих, за яким поки що закріплені вихідні дні). Ідеологічне підґрунтя щезло, ці вихідні не мають символічного навантаження, не відіграють консолідуючої функції, але все ще є частиною українського габітусу, адже ці весняні дні традиційно використовуються для певних землеробських робіт. "Відібрати" їх, не комунікуючи $з$ населенням як "стейкхолдером процесу", і не дати якоїсь адекватної заміни буде складно. Ситуація більш проблематична у відношенні православних свят. Попри законодавчо закріплену в Україні свободу совісті та відокремлення церкви від держави більшість українського населення залишаються православними, а тому закріплення державного вихідного за цим святом видається цілком закономірним. Водночас, відповідно до ст. 35 Конституції, Україна є світською державою, у якій проживає велика кількість людей різних віросповідань. Збереження за релігійними святами статусу загальнонаціональних вимагає істотної ревізії їх символічного змісту, яка, зважаючи на цивілізаційний вибір України, передбачає не тільки їх узгодження із міжнародним стандартом (григоріанським календарем), а й долучення світського символічного ряду, який може бути суголосним представникам усіх наявних в Україні віросповідань.

Поряд із національними святами важливе значення для маніпуляції суспільною свідомістю має практика спорудження пам'ятників. Сюди ж примикає найменування (і перейменування) вулиць і установка меморіальних дощок тощо [13, с. 62]. У цьому контексті надзвичайно важливим є вироблення єдиної культурної стратегії держави, оскільки, як показує українська практика, комеморація може сприяти як консолідації суспільства, так і світоглядно-культурному розколу. Так, наприклад, відсутність чітких орієнтацій в українській символічній політиці призвела до того, що орієнтоване на різні історичні й суспільні цінності та ідеали суспільство почало розвивати полярні світоглядні та ідеологічні парадигми. Ця практика, як доводить В. Кравченко, особливо чітко проявилася за режиму президента Л. Кучми, який дозволив місцевим елітам корегувати історичну політику центру. Це зумовило інтенсивну фрагментацію та поляризацію культурного простору України: в одних областях на широку ногу відзначали старі радянські свята, в інших національні, в одних радянські назви вулиць змінювали на російські імперські, в інших - на австрійські імперські, проте повсюдно публічний простір українських міст і сіл почав стрімко наповнюватися місцевою символікою - назвами вулиць, меморіальними дошками, пам'ятниками, публічними церемоніями тощо [7, с. 470]. 
Історична пам'ять здатна впливати на своєрідність комеморації та визначати напрям останньої. Між тим цей взаємозв'язок актуалізується тільки у разі відсутності стратегічного вектора символічної політики держави. У таких випадках історична пам'ять стає засобом маніпуляції суспільною свідомістю зазвичай конкуруючих еліт вони використовують пам'ять як "побічний продукт минулого досвіду" заради реалізації власних амбіцій засобами комеморації. Така практика зазвичай породжує соціальну деструкцію, сформовану на світоглядному тлі тих відмінностей, що виникли в процесі комеморації. Відомий в українському інтелектуальному дискурсі концепт вододілу між "двома Українами", з відповідними їм осередками у Львові та Донецьку, на наш погляд, некритично акцентував обґрунтовані М. Шлемкевичем психологічні відмінності між населенням Лівобережної та Правобережної України, поєднуючи їх із маніпулятивними стратегіями політичної еліти. Між тим не можна ігнорувати зауваження дослідників щодо нівеляції цих відмінностей після Другої світової війни, яка стала результатом свідомої радянської політики, спрямованої на взаємне культурне зближення та "уподібнення уладу життя і уладу духу" [5, с.348] населення по обох берегах Дніпра. Попри це відсутність спрямованої на забезпечення національної єдності символічної політики дала свої результати - наразі ми маємо тривалий мілітарний конфлікт, в основі якого, поряд з іншим, лежить претензія на етнічне, мовне, політичне самовизначення населення східних регіонів України та Криму.

Взаємозв'язок пам'яті та комеморації яскраво проявляється і в характері наявного в Україні конфлікту, попри політичні маніпуляції щодо його сенсу. А. Мегілл стверджує, що на відміну від пам'яті як побічного продукту минулого досвіду "комеморація виникає з бажання спільноти, існуючої в даний момент, підтверджувати почуття своєї єдності і спільності, зміцнюючи зв'язки всередині спільноти через консолідацію їі членів у ставленні до минулих подій, або, більш точно, через спільне ставлення до подання минулих подій" [10, с. 116]. Фактично, у випадку дієвості пам'яті, населення окупованих сьогодні територій мало б солідаризуватися із населенням Центральної України, з якою їх поєднує не тільки культура, а й спільна історична доля. Однак, під впливом комеморації, російська мова в цьому регіоні стала тим символічним осердям, яке породило розрив політичної традиції, вивівши на авансцену історії імперські політичні проекти, наприклад образ Новоросії.

Наведені нами приклади є вагомим емпіричним матеріалом, який підтверджує висновки Е. Гобсбаума щодо функцій винайденої, зазвичай засобами комеморації, mрадиції. Вони, на думку дослідника, спрямовані символізувати і виражати соціальну близькість, ідентичність спільнот і націй, водночас легітимізуючи статус як соціальної групи, так і тих інститутів та влади, які цю групу репрезентують. Поряд з вказаним "винайдена традиція" соціалізує певні цінності, норми, правила поведінки [25, c. 9]. Інакше кажучи, "винайдена традиція" спрямована транслювати у суспільну свідомість відповідну часу, політичним обставинам, а також вектору цивілізаційного розвитку спільноти аксіологічну матрицю. Зважаючи на це, "традиції не розвиваються самостійно - вони створюються, відкидаються або змінюються людьми" [24, с. 14-15]. Значення деяких елементів минулого драматично змінюється на різних етапах історичного розвитку спільноти чи в різних соціальних групах.

Зважаючи на зроблені зауваги, маємо всі підстави стверджувати, що історичні факти та події ніколи не бувають об'єктивними, всі вони мінливі і, по суті, є продуктом інтерпретації тих, хто має більші або менші права на їх легітимізацію. Саме тому "процес визнання та подолання минулого визначається насамперед політичними інтересами та інтересами впливових суб'єктів" $[9$, с. 139], що, в свою чергу, породжує феномен вираз- но представлених в українському культурному просторі "конкуруючих традицій". Останні, як слушно зауважує В. Ачкасов, частіше проявляються в рамках поліетнічних соціумів, однак нерідко зустрічаються конфлікти між традиціями представників різних соціальних груп і політичних союзів [2, с. 128]. Мова в даному контексті йде передусім про символічне панування, під час якого конкуруючі сили прагнуть приватизувати публічний дискурс, використовуючи різні історичні події та символи для власних цілей. Причому учасники цієї конкурентної боротьби претендують на об'єктивність саме своєї точки зору, апелюючи до "об'єктивних" свідчень (історичних, літературних, археологічних тощо). Зважаючи ж на те, що історична свідомість будь-якої соціальної спільноти будується на протиставленні або уподібненні "Іншому", "конкуруючі традиції" можуть призводити до гострих конфліктів, спричинених страхом перед "Іншими", які уявляються "ворогами". Показовим прикладом в даному контексті може стати поширена в російських 3MI інформація, що має на меті дискредитацію ситуації в Україні та транслюється на території АТО, породжуючи опозиційні настрої щодо людей, які ще кілька років назад вважалися земляками. Зазначимо, що в даному випадку виявляється надзвичайно низький рівень об'єктивності індивідуальної та колективної пам'яті та високий маніпулятивний потенціал комеморації.

Варто зауважити, що в періоди гострих соціальних та політичних криз кожне суспільство стикається 3 явищем актуалізації минулого, що є ознакою кризи національної/етнічної ідентичності, оскільки повернення до минулого є одним із способів подолання цієї кризи. Цей процес відбувається в осмисленні відмінностей між "Ми" та "Вони", які $€$ значимими у певний історичний період. Відбувається, з одного боку, "демаркація" кордонів, 3 іншого боку - визначення і перевизначення "Нашої" спільної історії, оскільки в основі національної єдності, як справедливо зауважував Е. Сміт, завжди лежить уявлення про спільне історичне походження [14, с. 31]. Зважаючи на це, маємо всі підстави стверджувати, що актуалізація минулого виступає засобом самоідентифікації кризового суспільства шляхом пошуку відповідей на запитання "Хто ми?", відповідь на яке передбачає й визначення вектора, куди ми рухаємося. Минуле в таких випадках виконує роль "референтно значимого", з яким порівнюються і за яким оцінюються діяння сучасників. Слід підкреслити, що колективна пам'ять і політична традиція дієві тільки тоді, коли вони живі і змінюються, коли вони дають здатність розуміння світу політики, яка застосовується до актуальної практичної політичної діяльності. Не варто забувати, що коли "пишеться" колективна пам'ять, вона відображає певну політичну і суспільну кон'юнктуру, а не "об'єктивно" оповідає про минулі події. Як стверджує М. Фуше, "минуле має сенс лише на основі його застосування в сучасних умовах. Воно таїть в собі невичерпне джерело уявлень і аргументів, які можуть бути мобілізовані або, навпаки, вчасно забуті" [16, с. 12]. Історія, як і культура, "багатошарова", а історична, як і культурна, пам'ять має складну організацію, що робить її безцінним символічним ресурсом, тому національна ідентифікація може ґрунтуватися на будь-якому історичному шарі, який з точки зору політичної еліти є найбільш актуальним та/або вигідним "тут і зараз". Окремим питанням постає відповідальність культурної еліти, інтелігенції, наукового експертного середовища за долучення/обґрунтування щодо формування цього вибору. Згідно зі свіжими (квітень 2017) висновками експертів, ініціаторами політики формування загальнонаціональної ідентичності громадян "повинні виступити, в першу чергу, академічні наукові установи та організації громадянського суспільства (по 56 \% голосів експертів)". Ця теза говорить про виразну зміну фокуса щодо замовни- 
ків та імплементаторів політик, у тому числі політики формування ідентичності. "...експерти відмовляють чинним політичним елітам у спроможності взяти на себе ініціативу в питаннях консолідації суспільства та вироблення політики формування загальнонаціональної ідентичності, наголошуючи на лідерських ролях інтелектуальних еліт і громадянського суспільства" [15, с. 63]. Це має стати темою подальшого дослідження.

Висновок. Зважаючи на цивілізаційну "розірваність" українського соціуму, українська еліта разом з експертним середовищем та іншими стейхолдерами має цілеспрямовано визначати або "перевизначати" власну ідентичність, осмислюючи/переосмислюючи історико-культурну спадщину суспільства, конструюючи тим самим "символічний капітал" та певні соціокультурні практики, які створять ціннісні габітуси спільнот, що консолідують суспільство, водночас окреслюючи вектор його цивілізаційного розвитку.

Поряд із необхідністю цивілізаційного визначення важливу роль у процесі "винайдення традиції" та конструюванні колективної пам'яті відіграє широко деклароване прагнення "розлучитися" з радянським тоталітарним минулим. Радянська спадщина глибоко вкорінена в українському соціокультурному і політичному бутті, а притаманні їй маніпулятивні стратегії, цінності та практики $є$ ефективним засобом конкуренції політичних еліт у боротьбі за власні капітали. Не останнє місце займає й механічне повернення до інтелектуальних конструктів дорадянської доби, оскільки в їх основі лежали "об'єктивні ознаки" етнічної ідентифрікації, які в умовах поліетнічного українського суспільства не мають достатнього символічного капіталу для консолідації суспільства.

Проаналізовані дослідження засвідчують той фракт, відповідно до якого розлучення з етнічними чи комуністичними міфологемами повинне супроводжуватися створенням конструктивної програми українського майбутнього.

\section{СПИСОК ВИКОРИСТАНИХ ДЖЕРЕЛ}

1. Арнаутова Ю. Е. Метогіа: "тотальный социальный феномен" и объект исследования [Електронний ресурс] / Ю. Е. Арнаутова // Образы прошлого и коллективная идентичность в Европе до начала Нового времени. - 2003. Режим доступу: http://ec-dejavu.ru/m/Memory_medieval.html.

2. Ачкасов В. А. Роль политических и интеллектуальных элит посткоммунистических государств в производстве "политики памяти" / В. А. Ачкасов. // Символическая политика: сб. науч. тр. - 2012. - №1. - С. 126-148.

3. Бауман 3. Индивидуализированное общество / 3. Бауман; [пер. с англ. под ред. В. Л. Иноземцева]. - М.: Логос, 2005. - 390 с.

4. Бурдье П. Социология социального пространства / П. Бурдье; [пер. с франц.; отв. ред. перевода Н. А. Шматко]. - М.: Институт экспериментальной социологии, 2007. -288 с

5. Гринів О. Украйнська націологія: між двома світовими війнами. Історичні нариси. / О. Гринів. - Львів: Світ, 2008. - 432 с.

6. Грицай Е. Украина: национальная идентичность в зеркале Другого / Е. Грицай, М. Николко. - Вильнюс: ЕГУ, 2009. - 220 с

7. Кравченко В. Поневолення історією: радянська Україна в сучасній історіограсіії / В. Кравченко. - К.: "Часопис "Критика", 2011. - 455 с.

8. Лангевіше Д. Нація, націоналізм, національна держава в Німеччині і в $\in_{\text {в- }}$ ропі / Д. Лангевіше; [пер. з нім. О. Логвиненко]. - К.: "К.І.С.", 2008. - 240 с.

9. Маколи М. Историческая память и общество сограждан / М. Маколи. // Pro et Contra. - 2011. - № 1-2(51). - C. 134-149.

10. Мегилл А. Историческая эпистемология / А. Мегилл. - М.: Канон+, 2007. $480 \mathrm{c}$

11. Основні засади та шляхи формування спільної ідентичності громадян України. Інсформаційно-аналітичні матеріали до Круглого столу 12 квітня 2017 р.

12. Пламенац Дж. Два типи націоналізму / Дж. Пламенац; [антологія / упоряд О. Проценко, В. Лісовий ; літ. ред. Л. Білик]. - К.: Смолоскип, 2000. - 483 с

13. Романовская Е. В. Идентичность и коммеморация / Е. В. Романовская, Н. Л. Фоменко // Власть. - 2015. - № 7. - С. 81-84.

14. Романовская Е. В. Коммеморативные практики и историческое сознание / Е. В. Романовская. - Липецк: Першина, 2014. - 59 с.
15. Сміт Е. Національна ідентичність [Електронний ресурс] / Е. Сміт // К.: Основи. - 1994. - Режим доступу: http://itopys.org.ua/smith/smi.htm.

16. Фуше М. Европейская респубпика. Исторические и геограсические контуры. Эссе. / М. Фуше. - М.: Международные отношения, 1999. - 168 с

17. Хантингтон С. Кто мы?: Вызовы американской национальной идентичности / С. Хантингтон; [пер. с англ. А. Башкирива]. - М.: ООО "Издательство АСТ", 2004. $-635 \mathrm{c}$.

18. Хантингтон С. Столкновение цивилизаций [Електронний ресурс] / С. Хантингтон - Режим доступу: https://www.e-reading.club/book.php?book=61484

19. Шацкий Е. Утопия и традиция / Е. Шацкий. - М.: Прогресс, 1990. - 456 с.

20. Штомпка П. Социология социальных изменений / П. Штомпка. - М.: Аспект-пресс, 1996. - 416 c.

21. Eley G. Becoming national / G. Eley, R. G. Suny. - Oxford: Oxford univ. press, 1996. $-518 \mathrm{p}$.

22. Hobsbawm E. J. On history/E. J. Hobsbawm. - L.: New Press, 1997. - 357 p.

23. Hobsbawm E. The Invention of Tradition / E. Hobsbawm, T. Ranger. Cambridge: Cambridge University Press, 1983. - $322 \mathrm{p}$.

24. Nora P. Between memory and history: Les lieux de memoire / P. Nora. - N.Y., Oxford: Oxford univ. press, 1994. -7-24 p.

25. Shils E. Tradition / E. Shils. - Chicago: Univ. of Chicago press, 1981. - 213 p.

\section{REFERENCES}

26. Arnautova, Y.E. (2003). Memoria: "totalniy socialniy fenomen i obiekt issledovania [Memoria: "total social phenomenon" and the object of research]. Retrieved from http://ec-dejavu.ru/m/Memory medieval.html. (In Russian).

27. Achkasov, V.A. (2005). Rol polytycheskykh $i$ intelektualnyh elyt postkomunystycheskyh hosudarstv v proysvodstve "polytyki pamyaty" [The role of political and intellectual elites of post-communist states in the production of "politics of memory"]. In Symbolic Politics, Vol. 1, 126-148.

28. Bauman, Z. (2005). The Individualized Society. Moscow, Logos (In Russian).

29. Bourdieu, P (2007). Sociology of Social Space. Moscow, Institute of Experimental Sociology (In Russian).

30. Hryniv, O. (2008). Ukrainska natsiolohia: mizh dvoma svitoyymy vinamy. Istorychni narysy [Ukrainian Nationalism: between two World Wars. Historical Essays]. Lviv, Svit.

31. Hrytsai, E. (2001). Ukraina: natsionalnaia identichnost v zerkale Drugogo [Ukraine: National identity in the Mirror of the Other]. Vilnius, EHU.

32. Kravchenko, V. (2011). Ponevolennia istorieu: Radanska Ukraina v suchasnii istoriografii [Conviction of History: Soviet Ukraine in Modem Historiography]. Kyiv, Krytyka.

33. Lanhevishe, D. (2008). Natsia, nacionalizm, nacionalna derzhava $v$ Nimechchyni i v Evropi [Nation, nationalism, national state in Germany and in Europe]. Kyiv, K.I.S.

34. Makoly, M. (2011). Istoricheskaya pamyat i obshchestvo sohrazdan [Historical memory and society of fellow citizens]. Pro et contra, 1-2(51), 134-149.

35. Megill, A. (2007). Istoricheskaia Epistemologia [Historical Epistemology]. Moscow, Kanon

36. Osnovni zasady ta shliahy formuvannia spinoi identychnosti gromadian Ukrainy (2017) Informaciino-analitychni materialy do Kruglogo stolu 12 kvitnia 2017 roku The Main principles and ways of formation of the common identity of Ukrainian citizens. Information and analytical materials for the Round Table]. April 12. Kyiv, Tsentr Rosumkova.

37. Plamenats, D. (2000). Dva typy nazionalismy [Two types of nationalism]. In Anthology. Kyiv, Smoloskyp.

38. Romanovskaia, E.V. (2015). Identychnost i komemoratsia [Identity and commemoration]. Vlast', 1, 81-84.

39. Romanovskaia, E. V. (2014). Kommemorativnye praktiky i istorycheskoe soznanye [Commemorative practices and historical consciousness]. Lypetsk, Pershyna.

40. Smith, E. (1994). Natsionalna identychnist [National identity]. Retrieved from http://itopys.org.ualsmith/smi.htm.

41. Fushe, M. (1990). The European Republic. Historical and geographical outlines. Essay. Moscow, Intemational relationships (In Russian).

42. Huntington, S. (2004). Who are we? The challenges to America's national identity. Moscow, AST (In Russian).

43. Huntington, S. Stolknovenie zyyylysazyi [Clash of Civilizations]. Retrieved from https://www.e-reading.club/book.php?book=61484.

44. Shatskiy, E. (1990). Utopia and Tradition. Moscow, Progress (In Russian)

45. Shtompka, P. (1996). Sociology of social change. Moscow, Aspect-press (In Russian).

46. Eley, G. (1996). Becoming national. Oxford, Oxford univ. press.

47. Hobsbawm, E. J. (1997). On history. London, New Press.

48. Hobsbawm, E. (1983). The Invention of Tradition. Cambridge, Cambridge University Press.

49. Nora, P. (1994). Between memory and history: Les lieux de memoire. New York, Oxford, Oxford univ. press.

50. Shils, E. (1981). Tradition. Chicago, Univ. of Chicago press.

Надійшла до редколегії 01.11.17

Н. Ю. Кривда, д-р филос. наук, проф.

Киевский национальный университет имени Тараса Шевченко ул. Владимирская, 60, г. Киев, 01033, Украина

\section{КОНСТРУИРОВАНИЕ УКРАИНСКОЙ ИДЕНТИЧНОСТИ: ВЫЗОВЫ КОММЕМОРАЦИИ}

В статье осуществляется культурософский анализ концепции национальной идентичности в контексте "изобретения традиции". При формировании коллективной идентичности имеем основание считать, что "изобретение" соответствующей времени традиции является одним из главных средств преодоления стереотипов и практик, которые считаются устаревиими и не соответствуют возложенной на них функции - консолидации общества. Идеи, символы и "места памяти", которые получают новое содержательное наполнение, способствуют разрушению тех социальных моделей, которые поддерживались старой традицией, раз- 
рушая ее саму. Именно поэтому в процессе конструирования традиции прежде всего принимается во внимание то, что созвучно современности, актуализируется ею и соответствует поставленным политическим иелям, а "забывается" то, что препятствует их достижению. В данном контексте важное значение приобретает понятие коммеморации, которое выступает как действенный инструмент формирования коллективной идентичности и средство консервации исторической памяти.

Ключевые слова: идентичность, коллективная память, историческая память, коммеморация, консолидация, традиция, культура.

N. Y. Kryvda, Doctor of Philosophical Science, Professor

Taras Shevchenko National University of Kyiv

60, Volodymyrska Street, Kyiv, 01033, Ukraine

\section{CONSTRUCTING THE UKRAINIAN IDENTITY: THE CHALLENGES OF COMMEMORATION}

The article deals with the cultural and philosophical analysis of national identity concept in the context of the "tradition invention". During the formation of collective identity, there is a reason to believe that the "invention" of the corresponding time of tradition is one of the main ways of overcoming stereotypes and practices that are considered obsolete and do not correspond to the functions assigned to them - society consolidation. Ideas, symbols and "places of memory", that receive new meaningful content, contribute to the destruction of those social models that were supported by the old tradition, destroying it itself. In this context, the notion of commemoration becomes important, which appears an effective tool for the formation of a collective identity and a means of preserving historical memory.

The main goal of the article is to identify the fundamentals of national identity in its close relationship with tradition and informal memory, as well as to formulate the notion of commemoration as an effective instrument for the formation of collective identity.

Futhermore, alongside with the need for a civilization definition, an important role in the process of "inventing the tradition" and the design of collective memory is widely declared as a desire to "break up" with the Soviet totalitarian past. The Soviet legacy is deeply rooted in Ukrainian socio-cultural and political life, and the inherent manipulative strategies, values and practices are an effective means of competition of political elites in the struggle for their own capital. The mechanical return to the intellectual constructs of the pre-Soviet period is not in last place, since they were based on "objective signs" of ethnic identification, which, in a multi-ethnic Ukrainian society, lacked sufficient symbolic capital to consolidate society.

The analyzed researches testify to the fact that taking rejection of ethnic or communist myths should be accompanied by the creation of a constructive program of the Ukrainian future.

Key words: identity, collective memory, historical memory, commemoration, consolidation, tradition, culture.

УДК 130.2:39

В. А. Личковах, д-р філос. наук, проф. Національна академія керівних кадрів культури і мистецтв, вул. Лаврська, 9, м. Київ, 01015, Україна Volodymyr.lychkovakh@ukr.net, fatv@ukr.net

\section{ФІЛОСОФІЯ ЕТНОКУЛЬТУРИ - ЕТНОКУЛЬТУРОЛОГІЯ - ЕТНОКУЛЬТУРОГРАФІЯ}

У статті досліджується взаємозв'язок філософії етнокультури, етнокультурологї та етнокультурографії як складових сучасного культурологічного дискурсу. Мета статmі - розширити уявлення про структуру сучасного культурологічного знання, зокрема через аналіз співвідношення філософії етнокультури, етнокультурології, етнокультурографії. У зв'язку з цим важливим завданням є обґрунтування поняття етнокультурографії як науково-мистецького дискурсу, в якому в образно-художній формі репрезентуються ідеї, архетипи, сигнатури, цінності етнокультури. Розкривається методологічне значення філософії етнокультури для побудови концептуальних парадигм і понятійно-категоріального інструментарію етнокультурології та культурологічної регіоніки. Вперше у сучасних науках про культуру вводиться поняття етнокультурографії як репрезентації етнокультури в художніх образах літератури і мистецтва. Зокрема, етнографічний підхід до художньої творчості аналізується на прикладах малярства відомих українських художників А. Фурлета і О. Петрової.

Ключові слова: філософія етнокультури, етнокультурологія, етнокультурографія, репрезентація етнокультури, художній образ, сигнатура, архетип, Ольга Петрова, Анатолій Фурлет.

Постановка проблеми. Сучасна культурологія вже традиційно включає до себе чотири усталених компоненти: історію культури, теорію культури, практичну культурологію та культурологічну регіоніку (регіональну культурологію) [див., напр., 2]. Крім того, розрізнюють "фундаментальну" й "прикладну" культурологію. Методологічно ця теоретична структура базується на фрілософії культури, яка $€$ різновидом модерного фрілософського знання і межує з антропологією, соціологією, етикою, естетикою. На перетині цих наук існують культурантропологія, соціологія культури, теорії морального та естетичного виховання. У своїй інтегративній єдності вони складають важливий сегмент корпусу фрілософрько-культурологічних дисциплін, які $\epsilon$ основою сучасної гуманітаристики, розкриваючи гуманістичний сенс наук про людину, суспільство, культуру.

У зв'язку із впливом глобалізаційних процесів на альтернативне поглиблення етнонаціональних ідентифікацій, зокрема на пошуки етнокультурної тотожності націй, актуалізується теоретичний інтерес до етнічної, регіональної, локальної специфіки культур окремих народів, народностей, національних меншин. З'являється етнокультурологія - наука про культурні цінності етносів, суперетносів і субетносів, про становлення і розвиток національних моделей осмислення культури, геокультурних вимірів духовного життя нації. Аналогічні процеси відбуваються і в інших напрямках гуманітарного знання: К.-О. Апель зіставляє "універсалістську макроетику" й "етноетику" [1], активно розвиваються етнологія, етнографія, етнопсихологія, етноестетика тощо. Етнокульту- рологія інтегрує всі ці знання про особливості менталітетів, соціокультурного буття і свідомості націй, етносів, субетнічних груп і культурних регіонів.

Як і кожна наука, етнокультурологія має спиратися на певні принципи організації наукового знання, розкриваючи свої теоретичні змісти через систему специфічних концептів, категорій і понять. Звісно, методологічний базис і категоріальний апарат етнокультурології багато в чому $€$ спільним 3 теоретичним оснащенням фрілософії культури, але має і власні специфрікації провідних ідей, що окреслюють предметне поле і стрижневі змісти наукового аналізу етнонаціональних культур.

У цьому сенсі найвищим шаром методологічного фундаменту етнокультурології $€$ фрілософрія етнокультури система теоретичних знань, в якій осмислюються загальні закономірності виникнення, сутності й функціонування культурних цінностей окремих етнонаціональних спільнот і регіонів. Від етнокультурології вона відрізняється більш глибокою рефрлексивністю філософрського аналізу "духовної метафізики" культури, її етноментальних характеристик, геокультурних, в т.ч. регіональних, хронотопів. У предмет фрілософрії етнокультури входить "духовна географія" краю (Фосильйон), тобто його культурний "ландшафт", що складається з неповторної єдності географічних, етнографічних, соціально-психологічних і ментальносвітоглядних вимірів життя певних етнічних спільнот.

Аналіз досліджень і публікацій. Саме такий підхід до аналізу національних культур закладений у праці Г. Гачева "Національні образи світу" [3]. Відомий росій- 